\title{
FEDERALISM UNDER FIRE: THE ROLE OF THE SUPREME COURT OF CANADA
}

\author{
Katherine SWINTON*
}

\section{INTRODUCTION}

In the months and years ahead, Canadians will be engaged in an extremely difficult and often emotional discussion about the community which they desire-whether there can be a Canada without Quebec, whether the nation should be more centralized or decentralized, whether there must be equal treatment of all provinces or some type of special status for Quebec. But the shape of the Canadian federation in the year 2000 is not the topic of this article; rather, I discuss the role of the Supreme Court of Canada in the federal system. Necessarily the discussion draws on a brief description of the political environment, for one cannot divorce the Court's work from the context within which it functions.

The impact of globalization will also be an important consideration in the interpretation of the Canadian Constitution. Judges will be called upon to decide whether international arrangements to which Canada is a signatory and the global nature of markets require a rethinking of the distribution of powers so as to facilitate national action and to limit provincial ability to interfere with the market or to frustrate the application of international standards. At the same time, the Court can never ignore the powerful forces of regionalism that characterize Canada and must consider its role in preserving the potential for diversity in public policy that federalism seeks to ensure.

My concern in this article is the Supreme Court's role in the evolution of the constitutional distribution of powers, both in terms of substantive changes in the balance of power and the process by which change occurs. Thus, I shall discuss the ways in which the Court is capable of interpreting constitutional language to allow adaptation, using the issue of globalization to demonstrate the tensions in this interpretive role, especially in a period of crisis in the federal system. Secondly, I shall examine the Court's role in conflict resolution in the Canadian federal system, emphasizing the Court's impact on mechanisms used by federal and provincial governments to adjust the Constitution without formal amendment. In particular, I shall consider the

\footnotetext{
Copyright $\odot 1992$ by Law and Contemporary Problems

- Professor, Faculty of Law, University of Toronto.

I am grateful to Ken Swan, Ron Daniels, and David Schneiderman for their helpful comments on a draft of this paper.
} 
status and enforceability of intergovernmental agreements, an issue recently the subject of important litigation. The Court cannot avoid involvement in the crisis facing Canadian federalism; indeed, it may well create new difficulties or new opportunities for the federal system as it proceeds with its adjudicative role.

\section{II}

\section{BACKGROUND}

"Canada" is a Huron-Iroquois word meaning settlement or living place. In the centuries since Jacques Cartier first applied this term to the land around Quebec City, it has encompassed various geographic regions. It came to be the name of the country created in 1867 that originally included four provinces and now includes ten. ${ }^{1}$ The term may, again, take on new meaning. Many of Canada's inhabitants no longer accept the "settlement" or community in its present form of governance that spans from sea to sea.

In contemporary Canada, there is much debate about the community to which citizens wish to provide their allegiance and within which they wish to pursue, with others, their aspirations. While many continue to feel strong ties to the current geographically described nation called Canada, powerful forces of nationalism exist in Quebec, where the majority of citizens feel their first identity with their province, rather than the larger polity. Indeed, 60 percent of those polled in the summer and fall of 1990 favoured some form of sovereignty-association. For this group, two nations exist in the space that is Canada: Quebec, a French-speaking nation, and English Canada or "rest of Canada," that takes in the nine other provinces. ${ }^{2}$

While the forces of regionalism are strongest in Quebec, many Canadians in other provinces also feel alienated from the nation, express important loyalties to their region, and call for a more decentralized system of government. ${ }^{3}$ Coinciding with these forces for decentralization, or even disintegration, are persuasive voices arguing that the trends to regionalism are inappropriate in an increasingly interdependent world, with policy driven more and more by the international market and by supra-national governing institutions. From these individuals comes pressure for a much stronger national government that can rid itself of many unpleasant shackles of

1. A very brief history of the term Canada or "kanata" is found in James $\mathbf{H}$. Marsh, ed, 1 The Canadian Encyclopedia 322 (Hurtig, 2d ed 1988).

2. See, for example, the results of the CROP-L'actualité poll, in Portrait des Québécois, L'actualité 14 (Jan 1991), showing $64 \%$ of respondents in favour of Quebec sovereignty. That number has risen as high as $70 \%$ and dropped to as low as $40 \%$ depending on the question asked. The ambiguity of the term Canada is illustrated by the report of the Quebec Liberal Party, "A Quebec free to choose" (Jan 31, 1991), a strongly nationalistic document, in which references to Canada generally indicate that the term does not include Quebec.

3. An Environics poll shows that the number of Canadians who identify more readily with their province than with Canada has increased from 1980 to 1990 . In 1980,62\% identified more with Canada; that number fell to $49 \%$ in 1990 . Michal Adams \& Mary Jane Lennon, The Public 's I'iew of the Canadian Federation, in Ronald Watts \& Douglas Brown, eds, Canada: The State of the Federation 1990. 97, 105 (Queen's Inst Intergovernmental Relations, 1990). 
province-building and allow Canada to act more effectively in the international marketplace as an economic unit. ${ }^{4}$

III

\section{Canadian Federalism: Centralized or Decentralized?}

Canada's federal system cannot be encapsulated in a one-word description such as "centralized" or "decentralized," because the term would vary depending on the perspective adopted. Certainly, the legal constraints on the distribution of legislative powers in the Constitution Act, 1867, as interpreted by the Courts, would lead many to characterize the Canadian system as decentralized in comparison to many other federations. While the formal distribution of powers in the Constitution Act, 1867 contained elements suggesting a dominant role for the national government (including the assignment of the residual power, the criminal law, and the power to regulate trade and commerce), ${ }^{5}$ the Courts early on, in a trend begun by the Privy Council and continued by the Supreme Court of Canada, 6 imposed constraints on the federal government's powers and expanded the provincial role to regulate business and commercial activity through a very generous interpretation of the power to legislate over "property and civil rights." 7 Thus, the federal government could regulate only interprovincial and international trade and commerce, leaving the provinces with the power to regulate most labour law, consumer product standards, securities, and a great deal of financial activity in "near banks" 8 and insurance companies.

As the judges have expanded and contracted the scope of federal and provincial powers, some change resulted in the balance of power between the

4. See, for example, Richard Harris \& Douglas Purvis, Some Economic Aspects of Political Restructuring, in Robin Boadway, Thomas Courchene \& Douglas Purvis, eds, 1 Economic Dimensions of Constitutional Change 189 (Queen's John Deutsch Inst, 1991).

5. These powers are found in the opening words of $\S 91,91(27)$, and $91(2)$, respectively. The historical record contains much material suggesting that key Fathers of Confederation contemplated a very strong central government. Indeed, the American Civil War provided them with a clear lesson about the dangers of decentralization. Therefore, $\$ 91$ of the Constitution Act, 1867 gave what were perceived to be the most important powers to the federal government. For a discussion of the historical record and its limited use in Canadian constitutional interpretation, see Katherine E. Swinton, The Supreme Court and Canadian Federalism: The Laskin-Dickson Years ch 4 (Carswell, 1990) ("The Laskin-Dickson Years").

6. The Judicial Committee of the Privy Council was the final court of appeal for Canada until 1949, when the Supreme Court of Canada, established in 1875, became the final court.

7. The provinces' major legislative powers are set out in $\S 92$ of the Constitution Act, 1867 , with the most important being $\S 92(13)$, "Property and Civil Rights in the Province," a power originally included to protect Quebec's distinct civil law system, but which now encompasses much contractual and business activity. The Privy Council's generous interpretation of the provincial powers and its narrow interpretation of key federal powers has been controversial, as is well illustrated in Alan Cairns, The Judicial Committee and Its Critics, 4 Can J Pol Sci 301 (1971).

8. "Near banks" is a Canadian term for deposit-taking institutions, such as trust companies and credit unions, which are somewhat similar to American savings and loan institutions. Generally they come within provincial jurisdiction because they are not regarded as "banks" within the federal banking power in sections $91(15)$ and (16) of the Constitution Act, 1867 
two levels of government at different times in Canadian history. ${ }^{9}$ At the moment, the federal government appears to be in an ascendant role because of developments in the interpretation of the trade and commerce, and peace, order, and good government powers, which will be discussed in the following section.

But even if the Courts have circumscribed federal powers to legislate, the conclusion should not be drawn that the federal government is a weak actor in the Canadian governmental system. Indeed, even though the Constitution purports to confer exclusive jurisdiction on each level of government over the matters set out in sections 91 and 92, large areas of overlapping jurisdiction exist. Often this overlap has allowed the federal government to use different instruments to regulate matters that from another aspect fall within provincial jurisdiction. Thus, when the federal government faced constraints under the trade and commerce power in regulating competition, it used its criminal law power to deal with the problem, albeit not always with the range of policy instruments that it might have preferred. ${ }^{10}$

Most importantly, though, the federal government's expansive powers to tax and spend have been key elements in the design of public policy and, thus, in the characterization of the balance of power in the Canadian federal system. With an unlimited power of taxation and no legal constraints placed on the spending power to date by the courts, the federal government has been able to influence public policy through tax design and, more importantly, through extensive spending in areas of provincial jurisdiction." ${ }^{1}$ Thus, while social welfare and education are provincial matters, the federal government has played an important directive role in social assistance, post-secondary education, and health care policy through grants to the provinces or to individuals. ${ }^{12}$

In sum, the formal Constitution, as set out in judicial interpretations of the distribution of legislative powers, leaves the impression that Canada is relatively decentralized when compared to a country like the United States.

9. These changes are discussed, for example, in Guy Tremblay, The Supreme Court of Canada: Final Arbiter of Political Disputes, in Ivan Bernier \& Andrée Lajoie, eds, The Supreme Court of Canada as an Instrument of Political Change 179, 182 (U Toronto Press, 1986) ("Instrument of Political Change").

10. Until the decision of the Supreme Court of Canada in General Motors of Canada Ltd. $v$ City National Leasing, [1989] I SCR 641, the authority to regulate competition rested on the criminal law power, rather than the trade and commerce power, thus requiring the use of a criminal form (prohibition and penalty on the criminal model) for enforcement. The Court's decision in General Motors to uphold competition legislation under the trade and commerce power allowed resort to civil remedies such as damages.

11. The federal power over taxation in $\$ 91(3)$ is virtually unlimited, although the tax cannot be a disguised regulatory instrument within provincial jurisdiction. Attorney General Canada $v$ Attomey General Ontario, [1937] AC 355 (PC) (unemployment insurance reference). The federal spending power has not been the direct subject of Supreme Court of Canada adjudication, although Brown $v$ YMHA Jewish Community Centre of Winnipeg, Inc., [1989] 1 SCR 1532, 1547-49, references it and provides implicit approval. The Alberta Court of Appeal recognized the validity of federal spending in provincial areas of jurisdiction in Winterhaven Stables Ltd. $v$ Attorney General Canada, 53 DLR (4th) 413 (1988).

12. An excellent description is found in Keith Banting, The Welfare State and Canadian Federalism (McGill-Queen's U Press, 2d ed 1987). 
However, under the "informal" constitution, taking into account the range of policy instruments available to the federal government to influence provincial policy or to affect behaviour in areas of provincial legislative jurisdiction, Canada's system has the potential for a significant degree of centralization. ${ }^{19}$

Within this context, I turn to the role of the Supreme Court of Canada in the interpretation of the distribution of legislative powers. A final court in a federal system has three potential roles. First, it is an institution for the resolution of disputes between federal and provincial governments about the scope of their respective jurisdictions. In the course of this problem-solver's role, this final court may perform a second function by participating in the evolution and refinement of the constitution's language in response to a changing social context. In addition, through its decisions on the constitutionality of various policy instruments by which the federal and provincial governments can structure their relationships, the court can act as a facilitator, allowing other institutions to respond to the need for constitutional evolution. The following section is an examination of the Canadian Supreme Court's role in the evolution of the Canadian Constitution, leaving a discussion of policy instruments to the final section preceding the conclusion.

\section{IV}

\section{Rigidity and Flexibility in Constitutional InTERPRetation}

Federal constitutions tend to be characterized by a degree of rigidity in order to protect the distribution of legislative authority between the two levels of government. The Canadian Constitution was for many years an extremely rigid one. Until 1982, the Constitution had no domestic amending formula to change the distribution of powers, and there was a convention requiring, if not unanimity, a substantial degree of provincial consent to make any alterations. ${ }^{14}$ As a result, there were only three formal amendments to the distribution of powers between 1867 and $1982 .{ }^{15}$ Yet constitutions also require a degree of flexibility in their language to allow them to adapt to the changing social and economic context. While the Canadian Constitution has had few formal amendments, there have been substantial modifications to the

13. I say "potential" because the current federal government under the leadership of Prime Minister Brian Mulroney seems intent on reducing its role in provincial areas of jurisdiction, in part because of the burden on the federal debt that has accompanied the funding of social programs by Parliament. Thus, there is a move toward decentralization, especially in social policy, that is fiscally motivated.

14. Amendments affecting the distribution of powers required action by the Parliament of the United Kingdom, which would only act on a request from Canada. The Supreme Court of Canada held in Reference re Amendment of the Constitution (Nos 1, 2, 3), 125 DLR (3d) 1, 103 (SCC 1981) ("Patriation Reference"), that a convention requiring a substantial measure of provincial assent was necessary.

15. These changes involved unemployment insurance (added to $\$ 91$ in 1940) and old age pensions and supplementary benefits (made an area of concurrent federal and provincial jurisdiction in $\$ 94 \mathrm{~A}$ in 1951 and 1964). The amending role of the United Kingdom ended in 1982 with the enactment of the Canada Act, 1982, ch 11 , $\$ 2$ (UK). At that time, a further amendment to the distribution of powers occurred, $\$ 92 A$, dealing with natural resources. 
document's content through judicial interpretation, and the Court continues to be an important institution for constitutional evolution.

There is an over-used phrase in Canadian jurisprudence that the Constitution is a "living tree," which is taken to mean that the Constitution must be interpreted "progressively" in order to take into account the changing nature of the country. ${ }^{16}$ The application of the living tree analogy to the distribution of powers under the Constitution has created controversy, for too often "progressive interpretation" meant centralization. In particular, the application of progressive interpretation to the federal "peace, order and good government" power found in the opening words of section 91 of the Constitution has been a source of tension throughout Canadian constitutional history. ${ }^{17}$ That power allows the federal Parliament to deal with matters not listed in the provincial list of legislative powers in section 92 of the Constitution. However, in section 91 the federal Parliament also has a detailed list of enumerated legislative powers on which the courts prefer to rely whenever possible. The opening words of section 91 have come to have at least two functions: an emergency power, allowing the federal Parliament to legislate to deal with national crises, and a residual power, allowing it to deal with matters not covered by the existing allocation of powers. At various times, there has been a third use, the "national dimensions" or "national concerns" doctrine, allowing the federal Parliament to deal with matters that are inherently of national concern. ${ }^{18}$

Opposition to the national concerns doctrine has been most vociferous among Quebec scholars, although they have not been alone. Many have described with foreboding the ease with which one can characterize problems as national because they occur in more than one province or have spillover effects. ${ }^{19}$ As a result, scholars and judges have tried to put limits on the doctrine, with the latest attempt in $R$. v. Crown Zellerbach Ltd., where a narrow majority of the Supreme Court of Canada stated:

16. Edwards v Attorney General Canada, [1930] AC 124, 136 (PC). The case is celebrated today because it determined that women were "persons" eligible to be appointed to the Senate despite the common law disability faced by women seeking to hold public office. The American equivalent to the "living tree" metaphor, to my mind, is Karl Llewellyn's The Constitution as an Institution, 34 Colum $\mathrm{L}$ Rev 1 (1934).

i7. The opening paragraph of $\$ 91$ of the Constitution Act, 1867 reads: "It shall be lawful for the Queen, by and with the Advice and Consent of the Senate and House of Commons, to make Laws for the Peace, Order, and Good Government of Canada, in relation to all Matters not coming within the Classes of Subjects by this Act assigned exclusively to the Legislatures of the Provinces . ...."

18. An overview of this doctrine, although slightly dated, is found in Peter W. Hogg, Constitutional Law of Canada ch 7 (Carswell, 2d ed 1985). The phraseology of the national dimensions doctrine comes from Attorney General Ontario v Canada Temperance Federation, [1946] AC 193, 205 (PC).

19. A good example of the Québécois perspective is the work of Jean Beetz, both as professor and Supreme Court judge. A description of Beetz's constitutional thought is found in Swinton, The Laskin-Dickson Years at ch 9 (cited in note 5). The following quotation from his dissent in.Reference re Anti-Inflation Act, [1976] 2 SCR 373, 445, shows his fears about characterizing problems traditionally provincial as national: "It is not difficult to speculate as to where this line of reasoning would lead: a fundamental feature of the Constitution, its federal nature, the distribution of powers between Parliament and the provincial Legislatures, would disappear not gradually but rapidly." 
The national concern doctrine applies to both new matters which did not exist at Confederation and to matters which, although originally matters of a local or private nature in a province, have since, in the absence of national emergency, become matters of national concern. ${ }^{20}$

A matter of national concern must have "a singleness, distinctiveness and indivisibility that clearly distinguishes it from matters of provincial concern," and the attribution to federal jurisdiction must be "reconcilable with the fundamental distribution of legislative power under the Constitution." 21 One key indication of the first element is referred to as "provincial inability" - that is, a consideration of "the effect on extra-provincial interests of a provincial failure to deal effectively with the control or regulation of the intraprovincial aspects of the matter."'22

The scope of this new doctrine is still open to question, although there has been some elaboration in contemporary doctrinal development under the trade and commerce power. After more than 100 years of constitutional interpretation in which the federal government's power to regulate trade and commerce in section $91(2)$ of the Constitution was limited to the interprovincial and international flow of commerce, the Supreme Court upheld federal competition legislation under a new "general regulation of trade" doctrine, which allows Parliament to create policies aimed at the economy as a unit, rather than at a particular trade or business, despite its impact on intraprovincial business activity. ${ }^{23}$ Then Chief Justice Dickson, in his opinion for the Court, wrote that it was critical that the legislation was beyond the ability of the provinces, acting jointly or severally, to enact constitutionally, and the failure to include all the provinces would jeopardize the successful operation of the policy in other parts of the country. ${ }^{24}$ Thus, his criteria incorporate concepts of provincial inability, as does the national concerns doctrine, as well as a consideration of harm. At the same time, he acknowledged, as did Justice LeDain in Crown Zellerbach, that this doctrine required a case-by-case balancing of the interests of federal and provincial governments. ${ }^{25}$

20. [1988] 1 SCR at 432 .

21. Id.

22. Id. Justice LeDain purports to draw on an academic commentary to support this test and refers to an article by Dale Gibson, Measuring "National Dimensions," 7 Manitoba LJ 15 (1976). In fact, Professor Gibson uses the provincial inability concept much differently-to support national action when the provinces have no jurisdiction over the problem, as with extra-provincial pollution. The federal government then gets jurisdiction only over the "gap" in provincial powers. Justice LeDain, in contrast, uses the concept as part of a functional approach to determine whether intra- and extraprovincial aspects of a problem are so interwoven that they require uniform treatment. Moreover, his concern is not just provincial legal incapacity to deal with a problem, but their lack of political will to do so. His test is much more expansive of federal authority than Gibson's. Crown Zellerbach, [1988] 1 SCR at 433.

23. General Molors, [1989] I SCR at 660-61. The background to the trade and commerce power, including the origins of this doctrine, were elaborated by Justice Dickson in a concurring judgment in Attomey General Canada v Canadian National Transportation Ltd., [1983] 2 SCR 206, 256-68.

24. General Motors, [1989] 1 SCR at 662.

25. Id at 663 . 
The endorsement of the national concerns and general regulation of trade doctrines should cause uneasiness among those satisfied with the present arrangement of powers or interested in a less, rather than more, centralized system of government. Once again, the tools for progressive interpretation are available to those desiring a stronger national government at a time when the demands from Quebec in the political arena are for significant decentralization. ${ }^{26}$ The forces of globalization will undoubtedly provide opportunities to argue for the application of these doctrines to strengthen the federal government's legal position.

While the term "globalization" is invoked commonly today, one cannot be sure that there is consensus on its meaning. ${ }^{27}$ I shall use it to encompass two important and related trends. First, it refers to the expansion of international trade, which is characterized by a dismantling of tariff barriers and increasing international competition not only in manufacturing, but in services and financial markets as well. ${ }^{28}$ The various rounds of the General Agreement on Tariffs and Trade ("GATT") have reduced tariffs significantly, ${ }^{29}$ while the Canada-U.S. Free Trade Agreement ("FTA") not only further reduces tariffs between the two countries, but also includes many important provisions dealing with the treatment of services and security of energy supplies, and a commitment to negotiate a subsidies code. ${ }^{30}$ This increase in global competition imposes new pressures on domestic businesses and national economies, while at the same time reducing the capacity of governments to control economic policy.

The second aspect of globalization is the trend toward supra-national government-that is, to the increasing regulation of conduct, whether of corporations, individuals, or states, at the international level. Much of this standard setting is in the trade area, with the GATT and the FTA as good examples, but there are numerous international regulatory efforts not so directly related to global competition. Good examples are found in the numerous environmental agreements or the increasing number of human rights documents, such as the recent convention on the rights of the child. ${ }^{31}$

Both aspects of globalization raise concerns in the interpretation of the Canadian Constitution, for provinces often have the ability to impose barriers on the movement of goods, services, capital, and labour that interfere with the

26. For an overview of the degree to which constitutional law and Quebec political thought have converged and diverged, see Andrée Lajoie, Pierrette Mulazzi \& Michèle Gamache, Political Ideas in Quebec and the Evolution of Canadian Constitutional Law, 1945 to 1985, in Bernier \& Lajoie, eds, Instrument of Political Change at 1 (cited in note 9).

27. Thomas Courchene discusses various meanings of globalization in Thomas Courchene, Global Competitiveness and the Canadian Federation 4-18 (mimeo) (U Toronto Conference on Global Competition and Canadian Federalism, Sept 15, 1990).

28. See, for example, Michael E. Porter, The Competitive Advantage of Nations ch 2 (The Free Press, 1990).

29. General Agreement on Tariffs and Trade, 55 UNTS 194, No 814 (1950).

30. Canada-U.S. Free Trade Agreement Implementation Act, SC 1988, ch 65. Schedule-Part A contains the text of the agreement.

31. Convention on the Rights of the Child, UN Doc A/44/736, 28 ILM 1448 (1989). 
functioning of the Canadian economic union and reduce the gains that would come from greater integration in the national economy. Also, the provinces can frustrate international obligations that Canada undertakes or wishes to undertake. While the federal government can sign treaties, these obligations cannot be enforced domestically without implementing legislation, and only the government with jurisdiction over the subject matter of the treaty can pass the necessary legislation. ${ }^{32}$ Thus, in a convention dealing with labour standards or human rights, the provinces would have the primary competence to pass implementing legislation, since labour law is generally within their jurisdiction. Similarly, many activities regulated by international trade agreements, such as a prohibition on discriminatory pricing to favour domestic producers, may fall within provincial jurisdiction, with the result that a province's actions or inaction may put Canada in violation of international obligations. ${ }^{33}$

One solution to this problem would, of course, be a change in the law relating to the implementation of treaties, as has been suggested by one member of the Supreme Court of Canada and numerous academics. ${ }^{34}$ Undoubtedly, when issues relating to the implementation of the FTA or other international agreements reach the Supreme Court, arguments for changing the treaty implementation law will be made. Some would argue that the federal government should be able to pass implementing legislation for any international treaty signed; others would restrict the federal power to treaties dealing with subjects of national importance, invoking the same considerations that underlie the application of the national dimensions doctrine.

A change in treaty implementation law allowing unilateral federal action would be inconsistent with the protection of provincial jurisdiction and regional diversity that are key features of the Canadian Constitution. The proliferation of international instruments touching so many policy areas would lead to a vast accretion in the jurisdiction of the federal government through its unilateral action, without the safeguards that the Constitution's amending formula, or even the revised national dimensions tèst, would provide. Admittedly, the idea of federal implementation has its counterpart in the United States, as some Canadians have been quick to point out. However,

32. Attorney General Canada y Attomey General Ontario, [1937] AC 326, $351-52$ (PC) (labour conventions). A good summary of doctrine is found in Robert Howse, The Labour Conventions Doctrine in an Era of Global Interdependence: Rethinking the Constitutional Dimensions of Canada's External Economic Relations, 16 Can Bus L J 160, 163-71 (1990).

33. Ontario's discriminatory pricing of foreign wines has been the subject of a successful complaint under the GATT, and it is vulnerable under the FTA. Nevertheless, the province seems to have the power under the Constitution to impose such a policy. This issue is discussed in Douglas Brown, The Evolving Role of the Provinces in Canadian Trade Policy, in Douglas Brown \& Murray Smith, eds, Canadian Federalism: Meeting Global Economic Challenges?, 81, 105-07 (Queens' Inst Intergovernmental Relations, 1991).

34. Chief Justice Laskin in MacDonald v Vapour Canada, 66 DLR (3d) 1, 29 (SCC 1976), suggested this solution. Critics of the treaty power are discussed in Howse, 16 Can Bus L J at 163-71 (cited in note 32) and John Quinn, The International Legal Environment: An Overview, in John Quinn, ed, The International Legal Environment 1, 90-98 (U Toronto Press, 1986). 
a key point of difference exists between the two federal systems. In the American system, there is a built-in political safeguard for federalism in the composition of the Senate, which has a role in treaty ratification. ${ }^{35}$ The federally appointed Canadian Senate has never acted as a body protective of provincial interests, despite the regional nature of its composition. ${ }^{36}$ Indeed, the national institutions of government are frequently criticized for their failure to protect regional interests. The Senate does not fulfil that role, and the lower House cannot, because Quebec and Ontario possess disproportionate voices due to their larger populations and the traditional importance of Quebec seats, in particular, to the success of the governing party. ${ }^{37}$

An altered treaty power is not the only option available to deal with the impact of globalization. Existing legal doctrines already provide some check on the provinces' abilities to protect their producers. The federal trade and commerce power, section 91 (2), provides a negative constraint by prohibiting regulations that discriminate against non-residents or that set prices and suppiy conditions aimed at protecting local producers at the expense of those outside of the province. ${ }^{38}$ However, existing law is an imperfect solution, for it does not inhibit discriminatory action when the province acts as an owner, for example, setting prices in government liquor stores or awarding government contracts. Moreover, the provinces can restrict entry of foreign goods or services when they do so for a reason such as health and safety or consumer protection, even though the result may be to inhibit trade interprovincially or internationally. Such arguments have in the past justified provincial restrictions on foreign ownership of securities firms or differential requirements across provinces for the licensing of trades. ${ }^{39}$

35. The U.S. Senate's role in treaty ratification is set out in US Const, Art II, § 2(2), requiring two-thirds approval.

36. The Canadian Senate has 104 seats distributed among four regional divisions (the West, Ontario, Quebec, and the Maritimes), which each have 24 seats, with Newfoundland having six seats and the Territories one each (Constitution Act, 1867, \& 22). Despite this composition, the Senate generally acts as a partisan political body, since senatorial appointments are a popular form of federal party patronage.

37. Both the Trudeau Liberal government and the present Mulroney Conservative government have been elected with large numbers of members from Quebec. Western voters have been particularly critical of national institutions and their lack of voice. For a discussion of the problems of political safeguards in Canada, see Swinton, The Laskin-Dickson Years at 46-48 (cited in note 5).

38. Attorney General Manitoba y Manitoba Egg Ė Poultry Assoc., [1971] SCR 689; Central Canada Potash Co. v Gov't of Saskatchewan, 88 DLR (3d) 609 (SCC 1978). There is also a negative constraint found in $\S 121$ of the Constitution Act, 1867, prohibiting interprovincial duties on goods, and in the Canadian Constitution (Constitution Act, 1982) part I (Canadian Charter of Rights and Freedoms), \$ 6 ("Canadian Charter"), which gives an individual right to interprovincial mobility for labour (as seen in Black $v$ Law Society of Alberta, [1989] I SCR 591. Section 7 of the Canadian Charter may also provide some economic protection, as seen in Wilson v B.C. (Medical Services Commission), 53 DLR $(4 \mathrm{th})$ 171 (BCCA 1988).

39. Manitoba Egg E Poultry Assoc., [1971] SCR 689. See also Morgan v Attorney General Prince Edward Island, [1976] 2 SCR 349 (upholding provincial controls on non-resident ownership of land). The securities industry regulations are discussed in Philip Anisman, The Regulation of the Securties Market and the Harmonization of Provincial Laws, in Ronald C.C. Cuming, ed, Harmomization of Business Law in Canada 118 (U Toronto Press, 1986). 
For many concerned with Canada's position in the interdependent world, it is important that the federal government have the authority to enter into binding international agreements that the provinces cannot undermine. Also, those concerned argue that the federal government must have expanded jurisdiction to deal with a range of economic problems so that Canada itself becomes more integrated and less fragmented economically, allowing the country to compete more successfully in the international arena. Realistically, the best arguments to support these developments lie in the new general regulation of trade doctrine with regard to economic or trade issues, while the national dimensions doctrine is more likely to be invoked in relation to areas which go beyond the economic, such as the protection of the environment.

The key elements of both doctrines will be provincial inability and harm. However, the relevance of international regulatory action should first be discussed. Particularly with the national dimensions doctrine, the argument will be made that a matter is of national concern because it is of international concern once it becomes the subject matter of a treaty or international agreement. Certainly, there is indication in Crown Zellerbach that the international nature of a problem is relevant. The Court found that marine pollution is a matter of national concern and took note of the international character of marine pollution, as well as the degree of international regulation. ${ }^{40}$ The Court allowed the federal Parliament to regulate both provincial internal salt waters and water within its own jurisdiction. This holding implies that international regulation indicates national importance without being conclusive thereof and that a qualitative assessment must still be made.

This implication is indeed important. Canadian domestic arrangements should not be refashioned by the international regulatory agenda, even when Canada is a signatory to the international instrument. After all, Canada is at most a middle power whose preferences will not always shape the international document. The Constitution enshrined a federal system of government, which indicates that there can be diversity in the approach to the regulation of problems within Canada, even if these problems are of interest in many countries. There can still be advantages to local regulation and implementation despite the universality of a problem. By maintaining the present arrangement for the implementation of treaties, the diversity of interests across regions is more likely to be an influential consideration in the treaty-making process.

Thus, the elements of provincial inability and harm, and, ultimately, the question of balance in the federal system must next be considered. It is essential that the Court think very carefully about these criteria, for the result

40. Thus, in Croun Zellerbach, [1988] I SCR at 436, Justice LeDain states that "[m]arine pollution, because of its predominantly extra-provincial as well as international character and implications, is clearly a matter of concern to Canada as a whole." He then went on to discuss the Convention on the Prevention of Marine Pollution by Dumping of Wastes and Other Matters and a United Nations document on marine pollution. 
of applying either the national dimensions doctrine or the new general regulation of trade doctrine shifts powers to the federal government which the provinces would otherwise have exercised exclusively. ${ }^{41}$ When the Court invokes these doctrines, it acts as a constitutional reformer or designer. In the case of the national concerns doctrine, the Court reforms or designs with no textual guidance as to what is national, in contrast to the interpretation of the distribution of enumerated powers, where there is some indication of criteria of national and provincial salience. With these new doctrines, the Court must be aware of the important stakes at issue, not only in the particular case, but also in the balance of federal-provincial powers and in the repercussions for the health of the federal system. It must weigh considerations of economic efficiency, responsiveness to citizen preferences, the aspirations of Quebec and other provinces, the claims of the Canadian nation, and a number of other criteria. ${ }^{42}$ The task is especially delicate in a period of constitutional ferment like the present, where the political actors are actively engaged in negotiations about the distribution of powers, and a judicial decision can dramatically alter bargaining dynamics.

In considering the concept of "provincial inability" in its new doctrines, the Supreme Court has yet to make clear whether it means legal incapacity to deal with a problem, political incapacity to do so, or provincial unwillingness to act. These are different concerns, raising different questions. Thus, if the concern is lack of constitutional power to deal with a problem, the focus would be on issues such as the territoriality constraints on provinces and spillover effects. To use an example, one province might have difficulty in regulating in another province certain conduct designed to escape its securities laws, since the Constitution provides that a province can only regulate within its jurisdiction and does not have extraterritorial capacity. Similarly, a province would be unable to stop polluters in another province from exporting their product in certain circumstances, as in Interprovincial Cooperatives, where polluters licensed in Ontario hurt fisheries downstream in Manitoba. ${ }^{43}$ In the pollution case, one might invoke the national concerns doctrine to cure the problem, but the logical implication of allowing national action would be to fill a legal gap, not to permit regulation of water pollution in general. Similarly, the gap in the securities example, addressed under the

41. Admittedly, the doctrines create areas of concurrent jurisdiction (although this conclusion has been debated over time, as indicated in the judgment of Justice Beetz in Reference re Anti-Inflation $A c t$, [1976] 2 SCR at 444, where he suggested that the national dimensions power gave exclusive jurisdiction to the federal Parliament). Justice LeDain left this conclusion open in Crown Zellerbach, [1988] I SCR at 433-34, while Chief Justice Dickson held that the power over competition was concurrent in General Motors, [1989] I SCR at 681-82. Nevertheless, paramountcy rules ensure federal dominance in cases of conflict. See, for example, Multiple Access Ltd. v McCutcheon, [1982] 2 SCR 161, 190-91.

42. For a discussion of these criteria, see Kenneth Norrie, Richard Simeon \& Mark Krasnick, Federalism and the Economic Union in Canada (U Toronto Press, 1986).

43. Contrast the holdings in Interprovincial Co-operatives Lid. $v$ The Queen in Right of Manitoba, [1976] I SCR 477, and R.v Thomas Equipment Ltd., [1979] 2 SCR 529. 
general regulation of trade doctrine, would allow federal attention to the offshore activity only. ${ }^{44}$

These outcomes do not seem to be the thrust of the new doctrines as envisioned by either Justice LeDain in Crown Zellerbach or Chief Justice Dickson in General Motors. Rather, these justices see the doctrines as more functional, providing a way of adding to federal jurisdiction new policy areas that have both intra-provincial and extra-provincial components. The language of functionalism is used by Justice LeDain in Crown Zellerbach, although he never applied the provincial inability criterion, so we really do not have a sense of how he would have done so. ${ }^{45}$ Chief Justice Dickson applied the provincial inability criterion in General Motors, and he clearly rejected an intra-provincial/extra-provincial distinction in allowing the federal government to regulate competition. ${ }^{46}$ It was not just anti-competitive activity transcending provincial boundaries that was brought within federal jurisdiction, but the whole range of competition policy.

The judicial perspective has shifted from the conceptual (that is, is this a problem with a situs outside the territorial reach of the legislature which might wish to regulate it?) to the functional (is this a problem affecting the national interest, even if much of the regulation will fall within a province?). Once we shift to the functional, we face the perennial problem of criteria for national importance. In General Motors, then Chief Justice Dickson seemed concerned about provincial incapacity to make policy, rather than their legal inability to do so, despite the language that he employed. In his view, an effective competition policy must include both interprovincial and intraprovincial activity, and only the federal government was capable of developing a policy "aimed at improving the economic welfare of the nation as a whole." 47 This quotation is the language of the Canadian economic union. The provincial incapacity here rests not only on problems of territoriality, although that is a consideration, but also on problems of limited vision, for then Chief Justice Dickson is skeptical of the provinces' ability to adopt a national perspective that could transcend their own regional interests. ${ }^{48}$

The dilemma persists: the Constitution, in its language and the interpretations thereof, allows the provinces to pursue their self-interest in the areas conferred upon them, even if the issues exist in more than one

44. This is Gibson's concept of national dimensions. Gibson, 7 Manitoba LJ 15 (1976) (cited in note 22 ).

45. Contrast the discussion by Justice La Forest in his dissent in Crown Zellerbach, [1988] 1 SCR at 458-59, of the provincial interest in regulating water pollution and the lack of evidence of harm from the failure of the provinces to act.

46. In General Motors, [1989] I SCR at 683, he explicitly rejected Quebec's argument to split jurisdiction, although his emphasis on constitutional incapacity suggests a jurisdictional focus.

47. Id.

48. The concern reflects an ongoing concern in Canadian politics-that is, whether Canada is a community of ten provinces, which together determine the national interest, or whether the national government is independent of the provinces in determining policy for the country. Then Chief Justice Dickson clearly opted for the latter view. 
jurisdiction. ${ }^{49}$ For a Court to shift that jurisdiction from them, sound principles and good reasons must exist, particularly in a period of negotiations among political actors for a realigned federalism. Indeed, one would expect that the national dimensions and general regulation of trade doctrines would rest on an empirical foundation, for the questions of provincial inability and the harm that flows therefrom are both factual in part. ${ }^{50}$

Language in both General Motors and Crown Zellerbach suggests that this expectation should be the case, ${ }^{51}$ although then Chief Justice Dickson in General Motors also stated that the presence of provincial regulatory action was irrelevant to the determination of federal competence. ${ }^{52}$ As a result, he did not really explore in detail the provincial record in the competition area. Indeed, it would have been difficult to do so, since the provinces have largely left this area to the federal government under the criminal law power.

If a major indication of federal competence is provincial inability and harm, the record of past regulatory efforts is clearly important. In other areas, such as securities regulation or the environment, the Court should consider the ability of the provinces to regulate and the harm of provincial inaction or diversity. In the securities area, for example, a good record of cooperation and harmonization among the provinces exists, with Ontario playing the leading regulatory role. ${ }^{53}$ This history of interprovincial cooperation should bring into question an argument for national regulation. ${ }^{54}$ Also, the values of provincial regulation, such as the experimentation in policy that may come in different jurisdictions, should not be forgotten. Moreover,

49. Justice La Forest notes this dilemma in his dissent in Crown Zellerbach, [1988] 1 SCR at 458. Justice LeDain also signals caution in shifting powers to the federal government when he notes for the majority:

The "provincial inability" test must not, however, go so far as to provide a rationale for the general notion, hitherto rejected in the cases, that there must be a plenary jurisdiction in one order of government or the other to deal with any legislative problem.

Id at 434 .

50. The Reference re Anti-Inflation Act, [1976] 2 SCR 373, would allow the introduction of extrinsic evidence to support the application of the doctrine.

51. Indeed, Justice Dickson's language in Canadian National Transportation Ltd., [1983] 2 SCR at 267, particularly suggests this when he says "[s]uch legislation is qualitatively different from anything that could practically or constitutionally be enacted by the individual provinces either separately or in combination" (emphasis added).

52. General Motors, [1989] I SCR at 683.

53. For a recent description, see Harvey Lazar, Global Competition and Canadian Federalism: The Financial Sector (mimeo: on file with author); Anisman, The Regulation of the Securities Market at 77 (cited in note 39 ).

54. Thomas Courchene argued for ongoing provincial regulation in this area. Thomas Courchene, Regulating the Canadian Financial System: Paradigms, Principles, and Politics, in Jacob Ziegel, Leonard Waverman \& David Conklin, eds, Canadian Financial Institutions: Changing the Regulatory' Environment I (Ontario Econ Council, 1985). His voice is lonely. See, for example, the contrasting view in Philip Anisman \& Peter Hogg, 3 Constitutional Aspects of Federal Securities Legislation in Canada: Proposals for a Securities Market Law for Canada 135 (Minister of Supply and Services, 1979); Anisman, The Regulation of the Securities Market (cited in note 39). 
the presence of federal jurisdiction does not guarantee uniformity of regulation or a policy more protective of the market. ${ }^{55}$

Admittedly, Justice LeDain spoke of the risks of provincial inaction, not just the record of harm, so that the tale of provincial cooperation would not end the argument for federal securities regulation. Recent examples indicate provincial failure to cooperate, and risks exist that harmonization can end. Moreover, industry bears additional costs because of the duplication of provincial regulation, as in filing requirements for prospectuses. ${ }^{56}$

This brings the discussion to the issue of the harm that would emerge from leaving regulation of the policy area to the provinces or splitting the ability to regulate between the two levels of government. These new doctrines require a consideration of the requirements of the specific policy area and, most importantly, the impact on the provinces of a transfer of jurisdiction to the federal government. These considerations suggest a need for detailed examination of the costs and benefits of the various regimes. For example, the costs of multiple regulation in the securities area would be weighed against the benefits of experimentation and emulation that can come with multiple jurisdictions in a federal system. ${ }^{57}$ More significantly, the Court must decide what weight it will give to economic values. The Canadian federal system to date has not placed a premium on economic considerations alone, but in addition has been governed by more amorphous concepts such as the value of regional or national community. ${ }^{58}$

This brings the discussion back to globalization and the pressures from international standard setting and competition. While the tendency will be to argue for more power for the federal government, one must be wary of such arguments, for there is ongoing value to the diversity of a federal system that should not be lost. ${ }^{59}$ Indeed, for those in Quebec, an expansion of federal

55. This point is well demonstrated in the communications area in Hudson Janisch \& Richard Schultz, Federalism's Turn: Telecommunications and Global Competitiveness, 18 CB L J 161 (1991).

56. See, for example, Richard Schultz \& Alan Alexandroff on Quebec's policy independence in Economic Regulation and the Federal System ch 4, $131-38$ (U Toronto Press, 1985).

57. That is, serious consideration must be given to the work of those economists who argue for the advantages of competition among jurisdictions. See, for example, Courchene, Regulating the Canadian Financial System (cited in note 54); Royal Commission on the Economic Union \& Development Prospects for Canada, 3 Supplementary Statement 486 (Minister of Supply \& Services, 1985) (a statement authored by Albert Breton) ("Macdonald Commission Report"). See also Ronald Daniels, Should Provinces Compete? The Case for a Competitive Corporate Law Market, 36 McGill L J 131 (1991).

58. The Court has traditionally rejected a focus on incidental costs in trade and commerce cases. See, for example, Carnation Co. v Quebec Agricultural Marketing Board, [1968] SCR 238; see also Swinton, The Laskin-Dickson Years ch 5 (cited in note 5). These newer doctrines seem to require some kind of balancing, which suggests a role for cost considerations, although not necessarily as the only consideration in the balance.

59. Indeed, Courchene argues that globalization will lead to weaker federal governments, since individuals will turn their loyalties to the closer, smaller governments. See Thomas Courchene, Canada in the 1990s: Coping with Internal and External Economic Change, in Brown \& Smith, eds, Canadian Federalism at 44-45 (cited in note 33). The problem with his thesis lies in his failure to consider the value of a national government as the country's voice in the international arena, especially in standard setting at that level. He also ignores the importance of the national government in redistribution of resources and correction of market failure. 
powers through judicial interpretation may only increase the momentum toward provincial sovereignty to protect Quebec's distinctness. While it is easy to argue that problems of capital market regulation or the environment transcend local boundaries, good arguments are presented for allowing jurisdiction to continue at the local level or to divide jurisdictions between national and provincial governments. Problems of the environment are of international interest, but they are also very important locally and can be addressed through various policy mechanisms. ${ }^{60}$ The province of Alberta may prefer a different tradeoff between development and protection of the environment than Prince Edward Island would choose. Similarly, the benefits of international trade may be great, but other values exist which should not be lost sight of. Especially as we regulate subsidies, future international standards might well put in to question important social programmes such as Medicare. ${ }^{61}$

The doctrines that the Court has recently invoked could allow some significant shifts in jurisdiction toward the centre; but before they are applied, the Court should have a strong empirical base for its decision to reallocate powers. In addition, it must finally come to terms with the values that influence the balance of powers in the federal system. If there is to be a greater emphasis on economic efficiency and spillover concerns, then the Court should consider the evidence on these issues in a much more rigorous way. Finally, in this process of power allocation, the Court must also come to terms with the difficult issue of the legitimacy of judicial review in federalism.

In sum, in the global village, there is still room for other levels of government within nations, perhaps guided by values other than the economic efficiency concerns that dominate discussions of global competition. While General Motors and Crown Zellerbach have provided arguments for expanded federal jurisdiction, one should be cautious in forecasting their impact. These two cases are quite distinct from the free trade, securities, or environmental examples that have been the underlying concerns in this section of the article. In Crown Zellerbach, marine pollution was held to fall within federal jurisdiction. Marine pollution has a very strong basis in federal jurisdiction because of its overlap with the territorial seas outside the internal waters of the country, navigation and shipping, and fisheries. ${ }^{62}$ The Court's language suggests that the addition of ocean waters within provincial boundaries to the federal powers was a modest accretion

60. Justice La Forest mentions this local concern with the environment in Crown Zellerbach Lid., [1988] I SCR at 433. See, for example, G. Bruce Doern, ed, Getting It Green: Case Studies in Canadian Environmental Regulation (C.D. Howe Inst, 1990).

61. Howse considers the impact on the provinces in his discussion of the application of these two doctrines to the United Nations Convention on Contracts for the International Sale of Goods (which he argues would be valid) and the Free Trade Agreement with the United States. He concludes that the latter would not be upheld under the doctrines because of its impact on the provinces. Howse, 16 Can Bus L J at $\mathbf{1 7 8 - 8 2}$ (cited in note 32).

62. The jurisdiction is found in a combination of the residual power and $\$ \S 91(10)$ and $91(12)$ of the Constitution Act, 1867. 
and quite defensible because of the interrelationship of polluting activity within and without provincial boundaries.

Similarly, the holding in General Motors is reasonable because it dealt with competition, a policy designed to facilitate the operation of the national economic union and remove barriers to internal trade. Indeed, competition law is part of the framework of an economic union. The federal government's claim to jurisdiction was strong, because of the Constitution's language and structural arguments. ${ }^{63}$ Moreover, Parliament had a longstanding presence in the field.

A significantly different set of considerations must enter the decisionmaking process when the Court is asked to consider matters under these new doctrines, such as the implementation of the United States-Canada Free Trade Agreement, for the interference with provincial jurisdiction is much greater. The Court has acknowledged that it must balance federal and provincial interests when applying these new doctrines. This task must be approached sensitively and cautiously. Globalization presents opportunities to consider these doctrines, but it must not be a catchword that obscures the need for careful case-by-case examination of the demand for an expanded federal role.

\section{V \\ The Court's Role in Intergovernmental Relations}

The Canadian federal system is characterized by a great deal of jurisdictional overlap despite the reference to "exclusive" fields of jurisdiction in sections 91 and 92 of the Canadian Constitution. The result is often duplication of effort by federal and provincial governments, as well as conflict in the operation of their policies. A federal decision to increase the number of immigrants has repercussions for provincial education and housing policy; a provincial decision to license a pulp and paper mill in its northern region may detrimentally affect native people or fisheries, both subject to federal jurisdiction. Therefore, there must be ways to deal with these problems of interdependence and mechanisms to allow the federal system to adapt to changing circumstances that may have made the original allocation of constitutional jurisdiction inappropriate.

The primary institution dealing with the problems of interdependence and change in the Canadian federal system has been executive federalism. Problems of interdependence and overlap are generally addressed through relations between the executives of the two levels of government, whether at

63. One of the major purposes of confederation was to create an economic union, and the original distribution of powers suggested an important role for the federal government in regulating that economy. See, for example, the ban on tariff barriers between provinces $(\$ 121)$, the trade and commerce power $(\S 9 \mathrm{I}(2))$, and the powers over banking $(\S 91(15)-(16))$, interest $(\$ 91(19))$, copyrights $(\S 91(23))$, and bills of exchange $(\S 91(18))$ in the Constitution Act, 1867. 
the level of first ministers, ministers, or officials. ${ }^{64}$ Various tools are used to resolve problems, including delegation of powers, intergovernmental agreements, use of the spending power, or ownership rights.

The Supreme Court also has a role to play in managing conflict and change in the federal system, but its role is secondary and, ideally, facilitative. How its decisions can adapt the language of the constitutional distribution of powers has already been discussed. The Court's attitudes toward the issues of concurrency of powers and the definition of conflict necessary to determine federal paramountcy affect both the agenda and the tenor of intergovernmental relations. ${ }^{65}$

The Canadian Supreme Court has not shied away from involvement in federal-provincial disputes. Indeed, it sees itself as the "guardian of the Constitution," 66 and the rules of constitutional litigation permit an activist role for the Court; the Court's involvement does not have to be tied to an actual dispute between parties. Thus, the Canadian model of adjudication is closer to the German constitutional court model than the American case or controversy approach because of its rules on standing and the reference procedure. The Canadian Supreme Court has developed generous standing rules for citizens to seek declarations challenging the constitutional validity of statutes. ${ }^{67}$ The Supreme Court Act provides a procedure for the federal cabinet to use in referring questions to the Court, and an automatic right to appeal from the decisions of references by the provinces to their Courts of Appeal. ${ }^{68}$ Under the reference procedure, a government can refer a contentious bill or law to the Court for a constitutionality determination even though a concrete dispute surrounding its application does not exist. References have often been used by governments as a tool in a federalprovincial dispute to obtain a determination about the validity of their own or another government's legislation. Even though the Court is drawn into the

64. A good description is found in $\mathrm{J}$. Stefan Dupré, The Workability of Executive Federalism in Canada, in Herman Bakvis \& William M. Chandler, eds, Federalism and the Role of the State 236 (U Toronto Press, 1987).

65. The Court has been very generous in finding concurrency, although the doctrines of exclusivity and interjurisdictional immunity provide limits. Chief Justice Dickson was particularly favourable to concurrency in General Motors, [1989] I SCR at 669 ("overlap of legislation is to be expected and accommodated in a federal state"). On paramountcy, the test for conflict has been narrow: whether the individual can comply with both laws. See Multiple Access, [1982] 2 SCR at 19091. There is some indication that this may be changing. See Bank of Montreal $v$ Hall, [1990] 1 SCR 121,154 (“[D]ual compliance will be impossible when application of the provincial statute can fairly be said to frustrate Parliament's legislative purpose").

66. Amax Potash Ltd. $v$ Gov't of Saskatchewan, [1977] 2 SCR 576, 590; Reference re Language Rights under the Manitoba Act, 1870, [1985] I SCR 721, 745.

67. Borowski v Allorney General Canada, [1989] 1 SCR 342 (the final case in a trilogy of standing cases, which describes its predecessors well). Borowski was granted standing to challenge the federal Criminal Code provision permitting certain abortions, although he had no special interest to protect.

68. Supreme Court Act, RSC 1985, ch S-26, §53 (reference procedure), $\S 36$ (appeals). For a discussion of the procedure and its history, see Barry L. Strayer, The Canadian Constitution and the Courts, ch 9 (Butterworths, 2d ed 1983). 
middle of some acrimonious disputes, it has answered the questions referred, except when there is insufficient information to allow an adequate response. ${ }^{69}$

The Court can become involved in some major political disputes through these devices, as well as through other cases that arrive via the ordinary routes of criminal or civil litigation (where the constitutional issue can be collateral to the main issue). Nevertheless, one should not overestimate the role of the Court in the management of the federal system. ${ }^{70}$ Often, litigation is a stage in the negotiation process between federal and provincial governments. The conclusion of the dispute can be very different from the formal legal arrangement articulated by the judiciary. For example, while the federal government "won" a dispute with Newfoundland over the control of the continental shelf off the province, ${ }^{71}$ it then entered into the Atlantic Accord with Newfoundland and conferred a substantial measure of this control on the province. $^{72}$

The judicial decisions are not irrelevant, nor insignificant, but they are not the final word. They are important to the federal-provincial negotiating process and affect bargaining power in important ways. This importance was evident in the Newfoundland case, where the Court's decision contributed to a resolution of a longstanding dispute. Similarly, in 1981, the Court's determination that the federal government could legally seek a constitutional amendment from the United Kingdom without provincial consent and that a constitutional convention required a substantial degree of provincial approval broke a deadlock in the federal-provincial negotiations over amendment of the Constitution. ${ }^{73}$

Beyond the allocation of bargaining power and the resolution of disputes, the Court can shape the devices or mechanisms whereby federal-provincial or interprovincial arrangements are effected. Over the years, the Court has expanded governments' power to delegate responsibilities to each other. ${ }^{74}$ Other instruments, such as the spending power, have generated little judicial guidance on legality. ${ }^{75}$ Recently, important issues involving the legal status of

69. See, for example, Reference re Legislative Authority of Parliament to Alter or Replace the Senate, 102 $\operatorname{DLR}$ (3d) 1, 16-18 (SCC 1979) (refusing to answer certain questions).

70. For a discussion of this role, see Patrick Monahan, Politics and the Constitution Part 3 (Carswell/Methuen, 1987); Swinton, The Laskin-Dickson Years at chs 1, 2 (cited in note 5).

71. Reference re the Seabed and Subsoil of the Continental Shelf Offshore Newfoundland, [1984] I SCR 86.

72. The Accord was entered into on February 11, 1985. A description is found in David Milne, Tug of War: Ottawa and the Provinces under Trudeau and Mulroney 99-102 (Lorimer, 1986). The content of the Accord can be found in the interlocking federal and provincial implementing legislation: Canada-Newfoundland Atlantic Accord Implementation Act, SC 1987, c3, as amended SC 1990, ch 41; The Canada-Newfoundland Atlantic Accord Implementation (Newfoundland) Act, SN 1986, ch 37 , as amended SN 1987, ch 25.

73. Reference re Amendment of the Constitution (Nos 1,2,3), 125 DLR (3d) 103.

74. The Court has moved from a very restrictive view of delegation in the early 1950s to a very generous view. Governments can delegate powers through a number of devices, such as conditional legislation, administrative delegation, and incorporation by reference. See Coughlin v Ontario Highway Transport Board, [1968] SCR 569; Re Peralta and the Queen in Right of Ontario, [1988] 2 SCR 1045. The remaining restriction is a prohibition on delegation of legislative power. See Attorney General Nova Scotia v Attomey General Canada, [1951] SCR 31 .

75. See discussion in note 11 . 
federal-provincial agreements have been raised in the courts, triggered by the federal government's efforts to reduce some of its financial burdens. ${ }^{76}$

The enforceability of intergovernmental agreements is important in a world where constitutional amendment is difficult; the failure of the Meech Lake Accord demonstrates this principle. ${ }^{77}$ One alternative to formal amendment is a federal-provincial agreement, as demonstrated by the Quebec-Canada Immigration Agreement, which allocates jurisdiction in ways satisfactory to the signatories without the uncertainty and complexity of formal amendment. ${ }^{78}$ Indeed, one veteran of the federal-provincial constitutional reform process has suggested the futility of a further attempt to redraft the distribution of powers, recommending that the next round focus on the use and design of flexible mechanisms for adaptation, such as intergovernmental accords. ${ }^{79}$ One problem with such devices is their enforceability, an issue that Canadian courts have rarely considered. To the extent that these instruments are relatively easy to change or are unenforceable, they may be unsatisfactory to a province like Quebec which is seeking a lasting rearrangement of jurisdiction. ${ }^{80}$ The remainder of this article looks at the nature of these agreements.

Little literature or case law exists on the nature of intergovernmental agreements, undoubtedly a commentary on the fact that the method for resolving disputes about obligations between governments tends to lie in the political, rather than the legal, arena. ${ }^{81}$ Indeed, some intergovernmental agreements are designed not to be enforceable in any other forum. Consider the type of document issued at the end of a First Ministers' Conference. An example is the commitment of the Premiers of Manitoba, New Brunswick, and Newfoundland to take the Meech Lake Accord back to their legislatures and to

76. Reference re Canada Assistance Plan, 71 DLR (4th) 99 (BCCA 1990), reversed by the Supreme Court of Canada in 83 DLR (4th) 297 (1991) ("CAP Reference").

77. The proposed Constitution Amendment, 1987 ("the Meech Lake Accord") died in June, 1990 because it failed to obtain the support of all the provinces before the three-year deadline for ratification expired. For an overview of the Accord and why it failed, see Richard Simeon, Why Did the Meech Lake Accord Fail?, and Pierre Fournier, L'échec du Lac Meech: un point de vue québécois ("The Failure of the Meech Lake Accord: The Point of View of Quebec"), in Ronald L. Watts \& Douglas M, Brown, eds, Canada: The State of the Federation 1990, 15, 41 (Queen's Inst Intergovernmental Relations, 1990).

78. A summary is found in Estanislao Oziewicz, Immigration Pact Called Step Forward, Toronto Globe \& Mail A7 col 2 (Feb 6, 1991).

79. J. Peter Meekison, Distribution of Functions: A Political Scientist's Analysis, in Ronald L. Watts \& Douglas M. Brown, eds, Options for a New Canada 259, 274-75 (U Toronto Press, 1991).

80. Quebec would not be concerned only about the legal status of such agreements, but also about their symbolic status. A constitutionally enshrined change in jurisdiction is obviously a much clearer affirmation of Quebec's distinct nature than an intergovernmental deal. On the other hand, Quebec's insistence that it will discuss matters only on a bilateral basis with the federal government may tend to restrict progress to executive agreements in the near term.

81. One of the few articles is David Mundell, Legal Nature of Federal and Provincial Executive Governments: Some Comments on Transactions between Them, 2 Osgoode Hall L J 56 (1960). This article spends a great deal of time on the legal nature of the Crown and is of minimal assistance to the issue with which I deal here. There is also some reference to the uncertain status of intergovernmental accords in the Macdonald Commission Report at 257-58 (cited in note 57). 
"use every possible effort to achieve" ratification before June $23,1990.82$ This commitment is hardly the kind of undertaking one would enforce through the courts. In contrast to these broad policy accords is a group of detailed agreements between governments, more in the nature of contracts (for example, the federal-provincial agreements under the Canada Assistance Plan ("CAP"), which will be discussed below). Between these two types of agreements lies a range of others, some quite detailed, some more in the nature of general policy commitments. In thinking about the issue of enforceability, one must keep in mind, as the courts are well aware, that disputes over some documents will not be justiciable. ${ }^{83}$

Nevertheless, some of these agreements will come before the courts, and this raises questions about their binding nature. The most recent example is CAP Reference, ${ }^{84}$ in which the province of British Columbia disputed the authority of the federal Parliament to reduce its obligations under CAP. Federal legislation allowed Ottawa and the provinces to enter into agreements whereby Ottawa would pay half the costs of provincially delivered social assistance. The legislation set out terms to govern the agreements, including a requirement of mutual consent for amendment or termination, or at least one year's notice of termination by either government. British Columbia and Canada entered into such an agreement in 1967. Trouble began with the 1990 federal budget, where, as part of a program of fiscal retrenchment, the Minister of Finance announced that grants under CAP would increase by no more than 5 percent for the three "have" provinces of British Columbia, Alberta, and Ontario. As a result, those provinces would no longer share costs equally with the federal government. A bill was introduced in the federal House to limit the contributions, with the language stating that its provisions took priority over the other parts of the CAP Act ${ }^{85}$ or any agreement. British Columbia quickly challenged the proposed federal action in a cleverly worded reference that was decided by its Court of Appeal before the federal legislation was enacted.

The decision of the Court of Appeal did not address the statutory authority of Parliament to amend the legislation or the agreement, since no legislation had yet been passed. Had there been legislation, the question of parliamentary sovereignty would have been clearly raised, with the argument being that Parliament could amend the Plan or any agreement thereunder. ${ }^{86}$

82. 1990 Constitutional Agreement, June 9, 1990. These three provinces were required to consent to the Meech Lake Accord by June 23, 1990. Ultimately, neither Manitoba nor Newfoundland voted on it before the deadline.

83. See, for example, the acknowledgement of this lack of justiciability in Minister of Finance of Canada v Finlay, [1986] 2 SCR 607 ("Finlay No. I"); CAP Reference, 7I DLR (4th) at 114-55 (Lambert)(referring to the role of the courts). The Atlantic Accord between Newfoundland and the federal government provides for binding arbitration to resolve certain disputes (section 27).

84. 71 DLR (4th) 99.

85. The bill was enacted by the Government Expenditures Restraint Act, SC 1991, ch 9, amending the Canada Assistance Plan, RSC 1985, ch C-1.

86. For discussions of parliamentary sovereignty, see Hogg, Constitutional Lau of Canada at ch 12 (cited in note 18); see also the classic, Albert Venn Dicey, An Introduction to the Study of the Lau' of the Constitution Part 1 (Macmillan, 10th ed 1959). Essentially, Parliament cannot bind its successors, and 
Indeed, the majority stated that there was no question that Parliament enjoyed the power to do this. ${ }^{87}$ Nevertheless, the majority's further findings indicated an important constraint on that sovereign power, for they held that a legal doctrine of "legitimate expectations" exists, which imposes a legal requirement that the Government of Canada, in these circumstances, obtain the consent of the province before seeking an amendment to the plan. ${ }^{88}$

The ramifications of this decision were very important, although the majority did not really examine them. The finding of a legal duty to consult and obtain consent before acting indicates that failure to do so would nullify any action taken without such consent; that is, the intergovernmental agreement is made binding according to its terms, which in this case would require at least one year's notice to terminate the agreement if the province did not agree to the change. The Court of Appeal did not say this, because the province did not seek relief to block the bill from proceeding through Parliament. ${ }^{89}$ However, the logical result of the failure to observe the legal duty would be to nullify any subsequent action.

One can sympathize with the provincial side, even though it is not surprising that $C A P$ Reference was overturned in an appeal to the Supreme Court of Canada. 90 The federal government had entered into an agreement to encourage the provinces to provide social assistance, a matter within provincial jurisdiction, and set certain broad conditions for the delivery of the program. For the federal government to change the terms of the arrangement unilaterally, without the notice contemplated by the agreement, is unfair to the provinces and imposes a financial burden that they had not contemplated when they designed their programs.

Justice Sopinka, writing for a unanimous Supreme Court, found that the terms of the federal-provincial agreement did not bind the federal government to pay a fixed sum. Rather, the agreement contained an obligation to pay the amounts authorized by statute. Therefore, the doctrine of parliamentary sovereignty ensured that there was no obstacle to keep the federal government from introducing legislation to vary its financial commitments. $^{91}$

Parliament, if supreme, can make or unmake any law within its jurisdiction in a federal system. Although parliamentary supremacy has been limited by the Canadian Charter, that change is not an issue in the situation under discussion.

87. CAP Reference, 71 DLR (4th) at 135.

88. Id at 135-36 (Toy). There is some indication that the doctrine might not apply had Parliament acted under emergency circumstances. Justice Lambert also held that British Columbia had legitimate expectations that it would be consulted before the plan would be changed. He did not describe this as a legal doctrine; rather, he used the words in their "ordinary meaning." Id at 120 . It is difficult to understand why he would deal with this issue if there was no legal force to the concept of legitimate expectations, for he places himself squarely within a political dispute, and judges generally try to avoid such action.

89. Indeed, there would be problems of parliamentary privilege and Crown immunity should this be attempted.

90. 83 DLR (4th) 297 (SCC 1991).

91. Justice Sopinka went on to discuss the special nature of intergovernmental agreements in the context of an argument that there was a want of mutuality if the federal Parliament could alter its obligations. 
The Court also rejected the application of the doctrine of legitimate expectations in these circumstances. ${ }^{92}$ At most, the doctrine gives the provinces a right to make representations and to be consulted; it does not confer a substantive right to consent to changes, as the Court of Appeal had held. More importantly, the doctrine has no application to legislative functions, and in this case can place no limits on Parliament itself or on the executive in introducing legislation in Parliament. ${ }^{93}$

CAP Reference indicates that parliamentary sovereignty reigns and that Parliament or a legislature has the ability to change its agreements without warning or in an unfair manner with the sanction being a political one, rather than a legal one. CAP Reference leaves it to the constitutional reform process to decide whether the Constitution should provide a mechanism for binding intergovernmental arrangements.

It is worth noting that the immigration agreement provisions of the Meech Lake Accord expressly provided a constitutional status for this class of intergovernmental agreements, but it did so with two checks. First, the agreements were subject to federal legislation, as amended from time to time, setting national standards and objectives relating to immigrants. Second, there was a parliamentary and legislative approval stage in the creation of such agreements, so that the agreements were not just the work of the executives. ${ }^{94}$

Agreements such as CAP are not subject to the same degree of parliamentary oversight, since the agreement is made by a minister with Cabinet approval. To make such agreements binding on future legislatures, one would want the safeguard of legislative ratification of the agreement and an awareness that the agreement would be binding according to its terms. This requirement would seem consistent with the Supreme Court's earlier decisions that intergovernmental agreements do not, by their own force, affect legal rights of other parties. Thus, in two disputes arising out of the application of the federal government's wage and price controls to the provincial public sector in 1975, the Court required legislation to implement the agreement and to limit rights existing under provincial laws and contracts. $^{95}$ One would want at least this legislative involvement before

This is not an ordinary contract but an agreement between governments. Moreover, [§] 8 [of the statute] itself contains an amending formula that enables either party to terminate at will. In lieu of relying on mutually binding reciprocal undertakings which promote the observance of ordinary contractual obligations, these parties were content to rely on the perceived political price to be paid for non-performance.

Id at 316 .

92. Id at $320-21$.

93. Id at 319,321 .

94. See the proposed $\S \S 95 \mathrm{~B}(2)$ (federal standards) and $95 \mathrm{C}(1)$ (approval process) of the proposed Constitution Amendment, 1987 (discussed in note 77). The Atlantic Accord provides for constitutional entrenchment should the necessary approval of the other provinces be forthcoming $(\S 64)$.

95. Reference re Anti-Inflation Act, [1976] 2 SCR at 435 (Chief Justice Laskin):

It is one thing for the Crown in right of a Province to contract for itself; it is a completely different thing for it to contract for the application to its inhabitants, and to labour 
federal and provincial agreements would bind future legislatures. However, even this safeguard is questionable. If an agreement is to limit legislative authority, there should be some clear signal of government intent, which suggests the need for special constitutional language, as in the Meech Lake Accord and earlier constitutional reform efforts. ${ }^{96}$

There may, nevertheless, be two legal constraints on governments seeking to change obligations. The courts have prevented the federal government from abrogating unilaterally agreements that brought a province into Confederation. ${ }^{97}$ As well, any legislative action must be within the enacting government's jurisdiction. Therefore, there may be some restraints on the provinces' abilities to change obligations that do not similarly constrain the federal government. Specifically, the territorial restriction on provincial jurisdiction can prevent the provinces from legislating changes to rights of those outside the province, as Newfoundland found when it tried to alter a power company's statutory lease (part of an unpopular arrangement to sell Labrador power to Hydro Quebec). The legislation would have canceled the lease, with the company's rights and assets reverting to the province. This was held to be an attempt to interfere with the power contract between the company and Hydro-Quebec. Provinces do not have the authority to interfere with extraprovincial contractual rights. ${ }^{98}$

To this point, my focus has been the abrogation of obligations, which is one aspect of enforceability. Equally important is actual enforcement of the obligations in the agreement. This issue arose in the CAP context when an individual sought to enforce federal obligations under the legislation and the agreement with the province of Manitoba. Mr. Finlay sought to restrain federal payments to the province, arguing that the provincial program to recover overpayments through deduction from current welfare and social assistance allowances violated the terms of the agreement and the federal statute requiring the province to provide the "basic requirements." $\mathrm{He}$ was accorded public interest standing in a case that went to the Supreme Court of Canada. ${ }^{99}$ Subsequently, he won on the merits, even though the federal government was not unhappy with Manitoba's action and, indeed, actually required Manitoba to institute an overpayment recovery scheme. ${ }^{100}$

organizations in the Province, of laws to govern their operations and relations without statutory authority to that end. This would be, in effect, to legislate in the guise of a contract.

See also Re Manitoba Government Employees' Association and Government of Manitoba, 79 DLR (3d) 1, 15-16 (SCC 1977).

96. These efforts are discussed in Meekison, Distribution of Functions at 279-82 (cited in note 79). The Macdonald Commission recommended a constitutional amendment to make intergovernmental accords binding according to their terms. Macdonald Commission Report at 258 (cited in note 57).

97. See, for example, Attorney General British Columbia v Attorney General Canada, 65 DLR (4th) 494 (BCSC 1989); The Queen in Right of Canada v The Queen in Right of Prince Edward Island, 83 DLR (3d) 492 (FCA 1977).

98. Churchill Falls (Labrador) Corp. v Attorney General Newfoundland, 8 DLR (4th) 1, 31-32 (SCC 1984). See also the cases cited in note 41 .

99. Finlay No. 1, [1986] 2 SCR at 633-34.

100. Finlay v Canada (Minister of Finance), 71 DLR (4th) 422, 443 (FCA 1990). 
The two Finlay cases, involving standing and the merits, are significant because they indicate that intergovernmental agreements are not the preserve of the signatory governments. In contrast to the third-party beneficiary rule in contract, which would have prevented Finlay from enforcing the contract, the Court gives the citizen status to patrol the intergovernmental relations process and to enforce obligations between governments. Finlay, whether in the standing context or on the merits, confirms that intergovernmental agreements are a special breed of instrument with issues of enforcement open to debate. As the courts become involved in issues surrounding them, it is clear that there will be different degrees of judicial oversight depending on the nature and detail of any particular agreement. Thus, it is difficult to generalize about their enforceability. As a result, while they provide a much needed tool to adapt the federal system, a degree of uncertainty exists about their efficacy, which makes constitutional amendment a preferred option for those seeking security and rigidity in their intergovernmental arrangements.

\section{VI \\ Conclusion}

Although the system has never been more vulnerable than it is now, Canadian federalism has been subject to critical scrutiny throughout the last three decades. The Supreme Court of Canada will not be at the centre of the process for constitutional renewal, but it does have an ongoing and important role in the federal system. ${ }^{101}$ Its decisions resolve disputes about jurisdiction, and it provides a method of incrementally adapting the language of the Constitution without awaiting the results of the difficult and rarely successful amendment process. Moreover, the Court's approaches to concurrency and paramountcy leave room for the instruments of executive federalism to address the issues of interdependence and overlap. Finally, its treatment of devices for constitutional adaptation, such as delegation and intergovernmental agreements, can facilitate the intergovernmental relations process in important ways. Nevertheless, while federalism in Canada is under fire, the Court must be careful lest its decisions create further problems in a country struggling to find a resolution of its constitutional conflicts.

101. Following the failure of the Meech Lake Accord, a new "Canada round" of constitutional reform began. The major focus for the debate is the federal government's 28 proposals, Shaping Canada's Future Together, launched September 24, 1991. 
。 